\title{
Quality in Air transport process of LOT Polish Airlines
}

\author{
Robert Rozenberg \\ Department of Flight Training \\ Technical University in Košice, Faculty of Aeronautics, \\ Slovak Republic \\ E-mail: robert.rozenberg@tuke.sk
}

\author{
Daniela Heralová \\ Department of Air Transport \\ Czech Technical University, Faculty of Transportation \\ Sciences \\ Prague, Czech Republic \\ E-mail: heraldan@fd.cvut.cz
}

\begin{abstract}
This article discusses the air transport process on scheduled long-haul flights of LOT Polish Airlines. Main focus is taken on price development of these routes. The introduction consists of a brief profile characterized LOT Polish Airlines. Next chapter summarizes the air transport process on scheduled longhaul flights. The frame of article is formed by price development statistics for scheduled long-haul flights to / from Beijing of LOT Polish Airlines and two other competing companies. Conclusion contains results of analysis and puts forward proposals to streamline of the air transport process on reviewed routes.
\end{abstract}

Keywords- air transport process, airline, analysis, price development, long-haul routes, LOT Polish Airlines, Boeing 787 Dreamliner

\section{INTRODUCTION}

Many people began to use opportunity free travel apart from own mother country after the labefaction of old government. People began to tend out on and discover not only states directly adjoining with their countryside but also foreign country for us many a time exotic country. Their aim of travel is different. Ones of them travel for work; others to family or for relax and adventure. This travel's demand was directed to progress of traffic as such. People want travel so quickest, most conveniently and in many cases so most generous of course. If passengers are deciding for air transport they have to choose with which airlines will flight. Typical companies offer their clients standard in a reasonable price in contrast from low expensive companies, which offer close price at the expense of comfort and confidences.

\section{COMPANY PROFILE}

LOT Polish Airlines is recognized as one of the eldest airlines in the world. LOT is a member of the International Air Transport Association IATA and also a part of largest airline alliance - Star Alliance. The headquarters of the airline is situated at Frederic Chopin Airport, which is located about 8 $\mathrm{km}$ south-west of Warsaw. Since its inception, LOT Company has undergone many stages of development. There are over 90 destinations in Europe, North and South America, Africa and Asia currently operated by LOT. The fleet consists of thirty- three aircrafts of five types - Embraer 170, Embraer 175, Embraer 195, Boeing 737-400 and Boeing 787 Dreamliner.

LOT is a joint stock company with majority ownership of the Polish government, another major shareholder is TFS Silesia and minority shareholders are also employees of the company. Polish Parliament has recently passed a bill that would have helped to privatize LOT Polish Airlines and therefore the state probably will not have a majority share.

On the other hand, in recent years, LOT has going through serious financial problems due to inefficient arrangement of activities, deteriorating competitiveness and global economic crisis. According to experts' forecasts, during this year the situation should be stabilized.

In view of the competitive struggle, the greatest threat for LOT on regional lines pose low-cost airlines Ryanair and Wizz Air and classic carriers Lufthansa and Austrian Airlines on long-haul flights and also on flights operated between Poland and Germany respectively Austria.

\section{AIR TRANSPORT PROCESS OF LOT POLISH AIRLINES ON LONG-HAUL ROUTES}

Air transport process presents complex of all activities associated with the provision of air transport services by the airline to the general public, starting with buying tickets, which means choosing the carrier, destination, travel class and the date of the flight, followed with arrival at the airport of departure and number of services provided at the airport before departure, further continuing with the flight itself and the services offered on board of aircraft during flight, and finishing with arrival at final destination and departure of airport. The extent and quality of these services vary depending on the nature of the air carrier, its economic and financial situation and due to other key factors.

As air transport is a complex process which consists of amount of partial activities and describing its course on all types of LOT routes would be too complicated and lengthy, this chapter will capture only air transport process of LOT on regular long-haul flights operated by Boeing 787 Dreamliner, which include two-way routes from Warsaw to New York, 
Chicago, Toronto and Beijing. The necessary information will be drawn from freely available sources and long-term statistics.

Based on an analysis of the air transport process on scheduled long-haul flights of LOT, we can conclude that airlines LOT provide its customers premium quality services. Already the first customer contact with the airline LOT, through the website, shows their highly professional approach. Internet purchase of air transport services of LOT is easily accessible and time-saving. The website is clear and available in several language versions, which contributes to increased customer satisfaction. LOT Company also participates in the largest frequent flyer program Miles \& More, in which participate all members of the airline alliance Star Alliance. Conditions of carriage on scheduled long-haul flights of LOT, regarding the categories of passengers, baggage categories and items excluded from air transport, by its very nature and character coincide with the transport conditions of other airlines. Slight differences may occur in the amount of fees for excess baggage and transport of animals and also in the luggage weight limits as these each company defines itself independently from the competition. Services provided to passengers at the airport before departure, thus the check-in process, security check, waiting before departure and onboarding process, subject to strict rules and internal regulations of the company. Their progress is monitored and coordinated by airline workers. LOT customers travelling on one of its regular long-haul routes have a choice of four check-in types check-in at the airport, web check-in, telephone check-in and self check-in. After completion of all necessary administrative activities connected with preparation for flight, passengers are mandatory to approach the security check, which is carried out by passing through the WTMD (Walk through Metal Detector) and if it is necessary security check continues with Handheld Metal Detector and/or palpation. Hand luggage is checked simultaneously with the passenger, and passing through a beltray equipment. Checked baggage passes through security check immediately after sampling a traveler during check-in process. Passengers on scheduled long-haul flights of LOT are allowed to wait for departure of their flights in the international departure hall. For passengers travelling in higher classes are also available two airport lounges. Boarding on long-haul flights is ensured by means of a movable boarding bridges. On long-haul flights of LOT there are deployed one of the most advanced transport aircraft currently - Boeing 787 Dreamliner, with a total capacity of 252 seats. Airline LOT offers long-haul flights in three travel classes - LOT Business Class, LOT Premium Class and LOT Economy Class. The main distinguishing parameter is the level of service and price. For customers looking for most cost-effective option is recommended travelling in LOT Economy Class. The compromise between the reasonable price and comfort is a LOT Premium Class. For the most demanding customers who require a high level of service is determined travelling in LOT Business Class. During long-haul flights, passengers are offered a variety of services. Free of charge are available to passengers on-board magazine Kaleidoscope, watching movies, playing games and listening to music. During the flight, food is served twice - for passengers of higher travel classes is included in the ticket price and for passenger of economy class is required to pay an additional surcharge.
Another service provided by airline during the flight is duty free sales of goods according to the offer of LOT's magazine Shop \& More. The hallmark of LOT is formed by wide variety of additional services upon arrival to the final destination, which include, for example, car rentals, booking a taxi or hotel, luggage delivery to the specified place and online tourist guide.

\section{PRICE ANALYSIS}

First routes between Warsaw and Beijing were operated in mid 80 s of last century. LOT launched renewed air traffic between Warsaw and Beijing based on code-share cooperation with the Chinese national carrier Air China in May 2012. Now a regular connection with the Far East is provided three times a week. Attraction for travellers may be the fact that these lines are operated by one of the most advanced transport aircraft currently - Boeing 787 Dreamliner. At first glance, offer to fly with LOT for a little bit of exotic to Beijing sounds very appealing. But what about the price offer?

In order to achieve a fair price analysis of the air transport between Warsaw and Beijing, except tracking the evolution of prices in a LOT, it was necessary to find other airlines providing air transport on similar routes and also monitor their price developments.

We found out that direct routes between Central Europe and Beijing offer two other airlines - German national carrier Lufthansa from Frankfurt base and Austrian carrier Austrian Airlines from the main airport Schwechat. Lufthansa operates flights between Frankfurt and Beijing each day in both directions using Airbus 380-800. Austrian Airlines provides two-way communication between Vienna and Beijing five times a week through the Boeing 767-300. Links from Vienna to Beijing are operated on Monday, Wednesday, Friday, Saturday and Sunday and links from Beijing to Vienna run regular on Monday, Tuesday, Thursday, Saturday and Sunday.

In terms of services offered, those are competitors with the highly related product offerings, not only due to the fact that these companies are traditional air carriers, but also all three companies are members of the airline alliance Star Alliance, and participate in a frequent flyer program Miles \& More.

Our aim therefore is to determine how the selected airlines differ in the price list for the offered products. Using this analysis, we can create a better picture of the pricing policy of LOT and we will be able to compare the results of the study area with the competition.

\section{A. Price development on routes to/from Beijing}

Over the period from 1 February 2015 to 31 March 2015, we have been tracking and recording price developments during the 14th week of 2015 (March 30-April 5) on regular long haul routes of mentioned airlines between their bases and Beijing.

LOT offers long haul flights in three travel classes - LOT Business Class, LOT Premium Class and LOT Economy Class. The main distinguishing parameter is the level of offered service and price. For customers looking for the most costeffective option is best choice travelling in LOT Economy Class. Compromise between reasonable price and comfort 
represents LOT Premium Class. For the most demanding customers who require a high level of service is determined travelling in LOT Business Class. Each of airlines has operating flights on analyzed routes in different travel classes, so we have taken into account all the specifics and focus just on two of them - economic (economy) and commercial (business) travel classes.

Next graphs reflect the price development of analyzed airlines on routes to/from Beijing in economy and business travel classes.

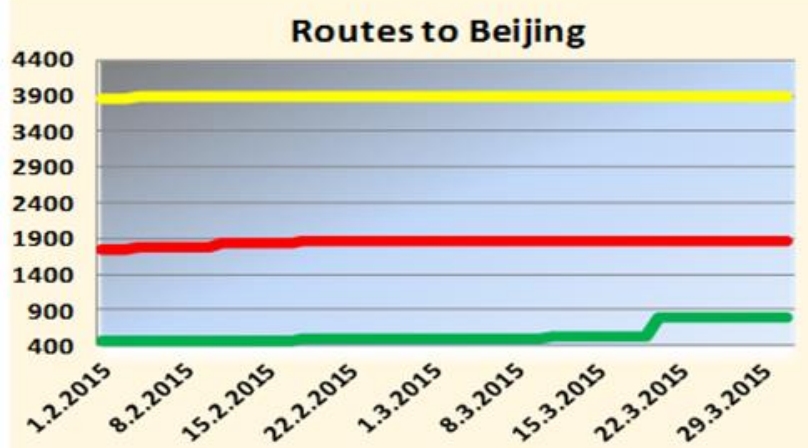

Figure 1. Price development on routes to Beijing in economy travel class

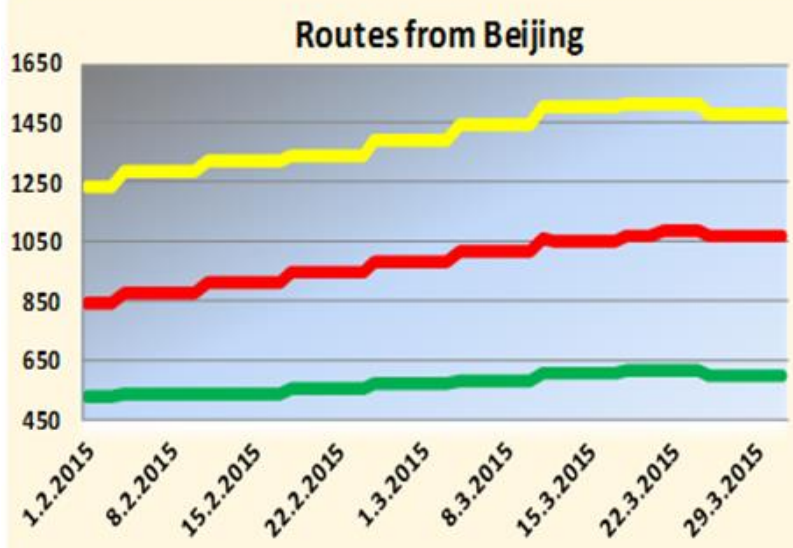

Figure 2. Price development on routes from Beijing in economy travel class

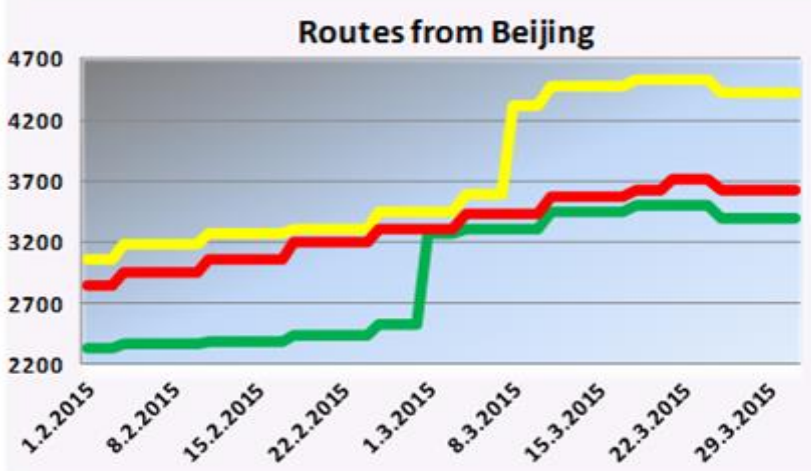

Figure 3. Price development on routes from Beijing in business travel class

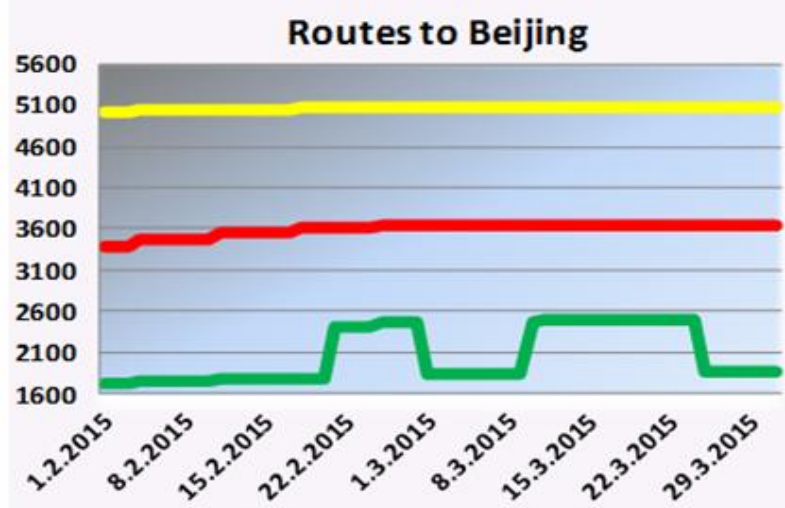

Figure 4. Price development on routes to Beijing in business travel class

\section{B. LOT Polish Airlines}

Aircrafts on flights from Warsaw to Beijing run every Tuesday, Thursday and Sunday. Return lines from Beijing to Warsaw are provided every Monday, Wednesday and Friday. During the reporting period, differences in prices between days of 14th week were recorded in economy class on flights from Warsaw to Beijing and in business class on both lines. Tuesday's air fare in economy class on flights from Warsaw to Beijing increased in the period from 20 March 2015 to 31 March 2015 by $56 \%$ compared to Thursday's and Sunday's flight. Next figure shows price development in economy class on flights from Warsaw to Beijing wherein green colour is for Tuesday 31 March, pink colour is for Thursday 2 April and yellow colour is for Sunday 5 April.

Prices of Tuesday's flight from Beijing to Warsaw in business class in the period from 21 February 2015 to 28 February 2015 increased by 35\%. 10 March 2015 was recorded marginal price increase Tuesday's and Thursday's flights by $35 \%$ compared to Sunday's flight, also from 11 March 2015 to 14 March 2015 there was an increase in prices compared to other flights. Sunday's deadline flights also about $35 \%$ on flights from Beijing to Warsaw were airfares Friday's flights in business class throughout March increased by $28.9 \%$ compared to Monday's and Wednesday's ticket prices as well as from 6 March 2015 to 9 March 2015 and subsequently from 15 March 2015 to 17 March 2015 airfares of Wednesday's flights were $28.9 \%$ higher. Changes between weekly ticket prices ranged from $-22.43 \%$ to $+28.9 \%$.

Fares development of LOT in business travel class on flights to Beijing have recorded several steep rise and fall. In the sixth week of ticket prices reached a maximum level of $2,497.90 €$. Over the past week, prices fell to $1,852.35 €$, representing approximately the same level as at the beginning of the period. Airfares on flights from Beijing to Warsaw have also registered rapid changes in development. During the analyzed period their height ranged from $2497.90 €$ to $3,398.83 €$.

\section{Lufthansa}

Price evolution for flights from Frankfurt to Beijing in Lufthansa economy travel class was not significant. Prices throughout the two-month period kept at around 3900€. In 
contrast, the prices of flights from Beijing to Frankfurt was changed regularly every week and were more than half the price. Fares started at level 1,237.32€, continued to grow up to a maximum of $1,517.90 €$ and stopped on the final amount of $1,481.79 €$.

Ticket prices of Lufthansa flights from Frankfurt to Beijing in business travel class were stable. During the analyzed period were maintained at around 5100€. Price evolution for flights from Beijing to Frankfurt was more dynamic. Ticket prices since the beginning of the reported period to the penultimate week ranged in value from $3,061.77 €$ to $4,536.22 €$. During the last week of March fell to 4,421.16€.

\section{Austrian airlines}

Economy travel class tickets from Vienna to Beijing offered by Austrian Airlines during the analyzed period have recorded no dramatic fluctuations, as in the case of Lufthansa. Ticket prices since early February have grown slightly, but by mid-February, their development stopped and was maintained at the same level until the end of March. Price level of mentioned flights ranged in value from $1,734.53 €$ to $1,870.03 €$. On flights from Beijing to Vienna in economy travel class were registered price changes every week. Prices rose from first to penultimate week and last week declined gradually, just as in case of competing companies. In numerical terms, airfares on flights from Beijing to Vienna ranged from $841.99 €$ in early February to $1,065.05 €$ at the end of March.

The Austrian Airlines price developments of flights on routes to / from Beijing in business travel class ran almost identically as for flights on those routes in economy class. Fares from Vienna to Beijing grew only the first three weeks, then stopped and their growth rates stood at 3,649.03€ until the end of the reported period. Ticket prices of return flights was increased during the first and penultimate week of $2,845.39 €$ to $3,717.73 €$ and noticed slight decrease to $3,624.36 €$ in the last week.

\section{E. Result arising from price analysis}

Clearly the most advantageous bid from the economic and business travel class, submit LOT Company, which provided several times lower ticket prices than competitors.

Ticket prices for the monitored lines of LOT were generally substantially lower than the ticket prices of competing companies. The reason for this is the current pricing policy of the airline, which promotes guarantee the most competitive prices. Airline in this way trying to attract the greatest number of passengers and to maximize the profit. Since the company went through serious financial problems in recent years, it was necessary or company management to intrigued a clear position on the future development and take the necessary steps to improve the situation. As part of the restructuring measures were amended timetable society change in the fleet, while the reorganization of labour. These changes necessitated a new marketing strategy that was designed to promote extensive advantageous bid of LOT.

Whereas the Chinese market is poised for even more massive expansion in the future, it is very good to know that direct air links with the Chinese capital Beijing is due to LOT
Polish Airlines readily available and accessible to the population of the Slovak Republic.

\section{PROPOSITION FOR STREAMLINING THE AIR TRANSPORT PROCESS ON ANALYZED ROUTES}

LOT short-term targets are contained in the restructuring plan, but long-term, strategic goals for the future are carefully protected by its leadership in order to achieve competitive advantage. Consequently, it is difficult to predict in which direction the development of LOT will continue. Views on the future of the airline LOT vary even in specialists' predictions. Some predict that the company LOT in few years will not be able to compete with low-cost airlines, which gradually absorb the Polish air transport market, with a potential solution to the declaration of bankruptcy or full privatization of the company. Other say that company after the restructuring measures will become a key player in the field of long-distance and regional air lines. Sebastian Mikosz, CEO of LOT Polish Airlines, in May 2014 during a press conference in Chicago, said that the year 2014 marks an important milestone in the modern history of the company. During this year there was recorded a consistent improvement in the financial position of LOT and began to write as a new era of its existence.

In 2015 the company plans to expand its fleet, and also add new destinations to the schedule. The choice of wide-body Boeing 787 Dreamliner for long-haul destinations of the company, despite initial complications, proved to be the right move and was able to attract a large number of passengers. For most new customers of LOT, flying on long-haul flights, was not a major boost when choosing the carrier the lowest bid, but paradoxically the opportunity to fly with one of the most advanced transport aircraft of present. Satisfaction with the Dreamliner is confirmed by the fact that the company implemented an order for eight more pieces of machinery.

In the future it will be able to expand into other long-haul routes, where it would be advantageous to focus on various destinations in Southeast and East Asia, which have a great economic potential. Direct air link between India, Vietnam and Japan and Central Europe through the airline LOT, could bring economic recovery on both sides and for society LOT of course this would mean an increase in the number of passengers and de facto an increase in operating profits. Prerequisite for the introduction of new routes should be to evaluation of the cost of their operation and choice of destinations with the lowest required investment. Another possibility of extending longhaul routes would be to introduce service between base in Warsaw and Australian cities Sydney or Canberra. Airline LOT by establishing direct links between Poland and Australia could cover a substantial hole in the aviation market in Central Europe, whereas at present no airline makes the non-stop connection of the two mentioned areas. The implementation of this proposal would not be sufficiently powered by Boeing 787-8, currently deployed on long-haul flights, but the company LOT would have to purchase at least the aircraft type series 787-9 with longer range that would be capable of given distance without any problems overcome.

Reasonable measures to raise efficiency in the air transport process on long-haul flights LOT would also increase the 
number of seats in the travel class LOT Premium Class. Many travelers looking for the most favorable quotations and comfort level while travelling so oblivious, but long-distance flights the situation is somewhat different. Passengers are more willing to pay extra for better service than on shorter flights and whereas LOT Premium Class represents a compromise between reasonable price and first-class services, it would be appropriate to add one row of seats in the travel class. With this step, there are seven seats by higher fares class, and it would potentially increase the operating profits of the company. Being aware of the real profitability would be possible to continue in this measure or return to the original cabin layout.

With regard to the services provided on board of the aircraft during the flight and after arrival to the final destination, the company LOT in comparison to competing airlines is on significantly better level. It offers to customers a wide range of different services, usually for an additional surcharge, which also helps to increase the company's revenue. The services provided at the airport before departure would bring some improvement by read-in Fast Track Line service. This is a toll service to fast track the flight for all passengers who do not like waiting in long lines at the airport. This service is currently accessible only for certain members of the FFP Miles \& More passengers and higher classes travellers. Introduction of the Fast Track Line can make this service available to all passengers regardless of travel class and, moreover, it could produce additional profit for airline.

\section{CONCLUSION}

The aerial transport process of company LOT is exerted and attested system. In general it is not different from an aerial transport process any kind of other aerial company. As the beginning of an aerial transport process could be consider buying of flight ticket. There the customer must make be sure what wants from an aerial companies and in due time communicate request. Before the arrival at the airport must the customer check if his luggage corresponds with indications which are given. If he do not done it, it make happened that he will be paid for luggage. After the arrival at the airport the customer is dispatch in the system, the board ticket is given to him, weight and check hand bags if has maximum dimensions, than is named. The traveler is crossing security check together with his hand bag. Consequently the passenger is waiting for the flight in the barrenness zone. There is offer by the Warsaw Chopin Airport many ways how to spend the time. Before the entered on the board is again check identity and with the assistance he is directed to his seat in the airplane. On the board of the plane is the customer informed with secure directions and there is offered to him services within the frame of reserve class. LOT is anxious to maximum satisfy their request of customers.

\section{REFERENCES}

[1] SZABO, S. et al. : Lietadlá dopravných spoločností., Košice : Letecká fakulta TU, 2007, ISBN 978-80-8073-740-5.

[2] SOCHA, L., KIŠ, S.: Perspektívy rozvoja leteckej dopravy, Nové trendy rozvoja letectva : 7. medzinárodná vedecká konferencia, Košice : Technická univerzita, 2006, ISBN 80-8073-520-4.

[3] KELEMEN, M., JEZNÝ, M., PULIŠ, P.: Letisko - komplex ochrany osôb, majetku a bezpečnostných technológií, Liptovský Mikuláš : AOS gen. M. R. Štefánika, 2010, ISBN 978-80-8040-413-0.

[4] SZABO, S.: Riadenie leteckej dopravy / Riadenie dopravy, Košice : Technická univerzita, 2005. s. 109-129. ISBN 80-8073-297-3.

[5] KOŠČÁK, P., FERENC, J.: Organizácia a riadenie prevádzky letísk, Košice : LF TU, 2010, ISBN 978-80-553-0356-7.

[6] KANDRÁČ, P., SZABO, S.: Niektoré aspekty zavádzania vel'kých dopravných lietadiel do služby. In: MOSATT 2005, 27th - 28th September 2005, Košice: SDS - SAV Košice, 2005. s. 208-214. ISBN 80-969106-1-2

[7] SOCHA, V., et.al.: Air accidents, their investigation and prevention, eXclusive e-JOURNAL 4/2014, Prešov, ISSN 1339-4509, [online]. Available at: http://exclusiveejournal.sk/4-2014/1-socha-socha-szabonemec.pdf

[8] HOSPODKA, J.: External Costs of Air Transport. In Workshop 2010. Praha: Ceské vysoké učení technické v Praze, 2010, p. 404-405. ISBN 978-80-01-04513-8

[9] PUDŁO, P. - GAVUROVÁ, B.: Riadenie nákladov na kvalitu, 1. vyd., Košice, TU, 2015. 111 s., ISBN 978-80-553-2023-6.

[10] PUŠKÁŠ, T., VAJDOVÁ, I., ENDRIZALOVÁ, E.: Vernostné programy leteckých spoločností, Exclusive Journal. Roč. 2, č. 4 (2014), s. 139-146., ISSN 1339-0260.

[11] SZABO, S., VAJDOVÁ, I.: Základy marketingu letiska 1, Košice : Multiprint - 2014. - 142 s., ISBN 978-80-89551-15-6.

[12] VAJDOVÁ, I., SOCHA, L', STOLÁRIKOVÁ, K.: TQM and safety in aviation, Bezpečnost a doprava : sborník konference : Teorie a Praxe v Bezpečnosti a Krizovém Řízení v Dopravě, 14. února 2014, Hradec Králové. - Praha : Institut Jana Pernera, 2014 P. 105-108., ISBN 978-8086530-92-5. 